\title{
IN-VITRO INTERACTION STUDY OF CEPHRADINE WITH DIFFERENT ESSENTIAL MINERAL SALTS AND ITS INFLUENCE ON ANTIMICROBIAL ACTIVITY (MIC) OF CEPHRADINE
}

\author{
S. M. Moazzem Hossen ${ }^{1 *}$, Md. Raihan sarkar ${ }^{2}$, Md. Shahidul Islam ${ }^{1}$, Abanti Barua ${ }^{3}$, Mohammad \\ Kamal Hossain ${ }^{1}$, Md. Sahamir Hossain ${ }^{1}$. \\ ${ }^{1}$ University of Science \& Technology Chittagong, (USTC), Chittagong, Bangladesh \\ ${ }^{2}$ Department of Pharmacy, Southeast University, Dhaka, Bangladesh \\ ${ }^{3}$ Department of Microbiology, University of Chittagong, Bangladesh
}

\begin{abstract}
Present paper describes the interactions of Cephradine with different essential mineral salt like Magnesium Sulfate, Manganese Sulfate, Ferrous Sulfate, Zinc Sulfate and Potassium Chloride in an aqueous system at pH 7.4. This Magnesium Sulfate, Manganese Sulfate, Ferrous Sulfate, Zinc Sulfate and Potassium Chloride are essential trace element. From spectrophotometric study, it has been found that Cephradine forms 1:1 complex with Magnesium Sulfate, Manganese Sulfate, Ferrous Sulfate, Zinc Sulfate and Potassium Chloride. Spectral studies helps to detect the initial complexation between drug and mineral salts. Job's plot at 7.4 provides same type of information. The Ardon's spectrophotometric method confirmed the 1:1 complexation and the value of stability constants was calculated using Ardon's plot. An individual antimicrobial study (MIC) of Cephradine in 1:1 mixture with Magnesium Sulfate, Manganese Sulfate, Ferrous Sulfate, Zinc Sulfate and Potassium Chloride at $\mathrm{pH} 7.4$ was performed. These studies were carried out by observing the minimum inhibitory concentration (MIC) of the complexes and compared with the parent Cephradine against both Gram negative and Gram positive microorganisms in nutrient broth medium. Study confirms interactions of the Cephradine with Magnesium Sulfate, Manganese Sulfate, Ferrous Sulfate, Zinc Sulfate and Potassium Chloride and the interactions results into change the antimicrobial activity of Cephradine.
\end{abstract}

\section{Corresponding Author:}

'S. M. Moazzem Hossen

Lecturer, Department of Pharmacy, University of Science \& Technology Chittagong (USTC).

Cell Phone: +880-01816071263, E-mail: hossen.Pharmacy@hotmail.com 
Result shows that the antimicrobial activity increasing trends in presence of Magnesium Sulfate, Manganese Sulfate, Ferrous Sulfate and decreasing trends in presence of Zinc Sulfate and Potassium Chloride.

Key words: Cephradine, Job's Plot, Ardon's method, MIC, Essential trace element.

\section{Introduction}

Cephradine is a semisynthetic cephalosporin antibiotic developed at the Squibb Institute for Medical Research ${ }^{1}$, chemically designed as 7-[D-2-amino-(1,4cyclohexadiene-1-yl) acetamido]-3-methyl-8-oxo-5-thia-1-azyabicyclo-octa-2-ene-2carboxylic acid ${ }^{2}$.

Ferrous sulfate USP is an important ingredient of ferrous sulfate U. S. P syrup, ferrous sulfate USP capsule and Ferrous sulfate USP tablet. Ferrous sulfate is the most widely used oral iron preparation and is considered as the drug of choice for treating uncomplicated iron-deficiency anemia. Zinc is an essential dietary mineral. Zinc deficiency is associated with impaired growth, parakeratosis (a thickened, scaly, inflamed skin) and retarded sexual maturation. Zinc sulfate is an important ingredient of Zinc sulfate syrup USP. Manganese, Ferrous, Magnesium, Zinc, Potassium and Chloride are essential trace ions ${ }^{3}$.

Gram-positive bacteria are usually sensitive, Staphylococcus aureus, including most penicillin-resistant ${ }^{4}$, but not methicillin-resistant strains, are sensitive. Cephradine is about as resistant as cephalothin to inactivation by Staphylococcal $\beta$-lactamase ${ }^{5,6}$. Most other aerobic Gram-positive cocci, such as Staphylococcus epidermis, Streptococcus pyogenes, Streptococcus pneumoniae and Streptococcus viridans, are susceptible to cephradine. Streptococcus faecalis is resistant ${ }^{7}$. Anaerobic Grampositive cocci, such as the Peptococcus and Peptostreptococcus spp., are usually cephradine sensitive. Most strains recovered from airway associated infections are relatively sensitive (MICs 8-16 g per $\mathrm{ml}$ ), but other strains are less $\mathrm{so}^{8}$. Against Gram-positive bacilli, cephradine has a similar inhibitory action to cephalexin.

Gram-negative bacteria like E. coli, Proteus mirabilis and Klebsiella spp. ${ }^{9,10,11}$ are susceptible. Cephradine is only moderately active against $N$. gonorrhoeae ${ }^{12}$ but it 
retains this activity against $\beta$-lactamase producing strains ${ }^{13}$. Cephradine is relatively inactive against H.influenzae, many strains of which are completely resistant to this drug ${ }^{14,15}$. The drug is moderately active against Gardnerella vaginalis ${ }^{16,17,18}$.

\section{Materials and method}

\section{Materials}

Cephradine, kind gifts from Medicon laboratories Ltd, Dhaka, Bangladesh. Magnesium Sulphate, Manganese Sulphate, Ferrous Sulphate, Zinc Sulphate and Potassium Chloride were from Merck Itd, Mumbai, India.

\section{Interactions (complexation) study}

\section{Spectral studies}

Initial detection of complexation of Cephradine with Magnesium Sulfate, Manganese Sulfate, Ferrous Sulfate, Zinc Sulfate and Potassium Chloride has done from the nature of spectra of pure compounds as well as their 1:1 mixtures in phosphate buffer solution of 7.4 at a fixed concentration $\left(0.1 \times 10^{-5}\right) \mathrm{M}$.

\section{Job's spectrophotometric method of continuous variation ${ }^{19}$}

In this method, series of absorbance of Cephradine with Magnesium Sulfate, Manganese Sulfate, Ferrous Sulfate, Zinc Sulfate and Potassium Chloride mixture with different molar ratios at $\mathrm{pH} 7.4$ were measured by keeping the total moles constant. The absorbance of Cephradine and Cephradine with Magnesium Sulfate, Manganese Sulfate, Ferrous Sulfate, Zinc Sulfate and Potassium Chloride solutions was measured at $262 \mathrm{~nm}$. The observed absorbance of the mixtures of various mole fractions was subtracted from the sum of the values for free Cephradine and Magnesium Sulfate, Manganese Sulfate, Ferrous Sulfate, Zinc Sulfate and Potassium Chloride. The absorbance difference (D) was then plotted against the mole fractions of drugs in the mixtures. A curve, thus, obtained showed a maximum at a point, which indicated the molar ratios of Cephradine and Magnesium Sulfate, Manganese Sulfate, Ferrous Sulfate, Zinc Sulfate and Potassium Chloride in the complex. 
Volume 1, Issue 2, Serial 3: September 2012

\section{The Ardon's spectrophotometric methods ${ }^{20}$}

In this method, concentrations of Cephradine varied while keeping the concentrations of Magnesium Sulfate, Manganese Sulfate, Ferrous Sulfate, Zinc Sulfate and Potassium Chloride fixed at 2x10-3 M. The whole experiment was performed in the buffer $\mathrm{pH}$ 7.4. The absorbencies were measured at $262 \mathrm{~nm}$. For calculation, the Ardon's equation was used.

This equation is given below:

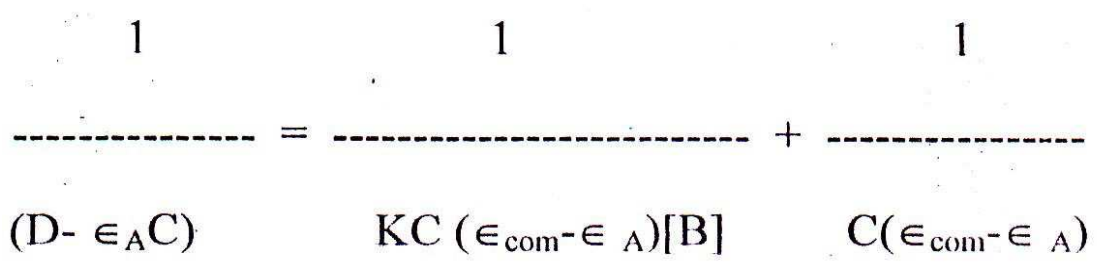

Where,

$\mathrm{D}=$ Absorbance of the mixture.

$\mathrm{B}=$ Molar concentration of the drug.

$\mathrm{C}=$ Molar concentration of the mineral salt.

$€ \mathrm{com}=$ Molar extinction co-efficient of the complex.

$\epsilon_{\mathrm{A}}=$ Molar extinction co-efficient of the drug.

The value of $\epsilon$ a was chosen as 1 , which is an essential condition for validation of the method. The value I or $I /\left(D-\epsilon_{A} C\right)$ were plotted versus $1 /[C]$ to get the straight lines. The concentration of all mineral salts was kept constant at 2x10-3 M (denoted by $\mathrm{C}$ in the equation) \& the concentration of interacting species Cephradine was varied (denoted by $B$ in the equation). The 1:1 complex gave a straight line in the plots with an intercept and a slope. The stability constant of the complex was given by the relation:

$\mathrm{K}=$ intercept / slope 


\section{Antibacterial Studies}

\section{Sample collection}

Organisms were employed in these studies were collected from department of microbiology, Chittagong University, Chittagong, Bangladesh.

\section{Determination of gram positive and gram negative Bacteria}

A smear of each organism to be stained was prepared on a clean grease free slide by taking a loopful of bacteria. The smear was air dried and then was heated by passing the slide quickly through a flame to heat fix. A drop of Ammonium oxalate crystal violate was added and kept for 1 minute. After that the slide was rinsed with tap water gently. Logul's lodine was applied and was rinsed with tap water. After that decolorizing agent, 95\% ethanol was added and kept it for 2 minutes. 1 to 2 drops Safranin was added as counter stain after washing the decolorizing agent. After 45 seconds the slide was rinsed up. By following this method the slide was prepared to differentiate the gram positive and gram negative bacteria under the microscope.

\section{Estimation of MIC (Turbid metric method to determine MIC)}

\subsection{Turbidity Standard for preparation}

To standardize the inoculum's density for a susceptibility test, a $\mathrm{BaSO}_{4}$ turbidity standard, equivalent to a $0.5 \mathrm{McF}$ arland standard was used. $0.05 \mathrm{ml}$ or $50 \mu \mathrm{l}$ of 0.048 $\mathrm{M} \mathrm{BaCl}_{2}$ or $1.17 \% \mathrm{~W} / \mathrm{V} \mathrm{BaCl} 2.2 \mathrm{H}_{2} \mathrm{O}$ was added to $9.95 \mathrm{ml}$ of $0.18 \mathrm{M} \mathrm{H}_{2} \mathrm{SO}_{4}$ or $1 \%$ $\mathrm{V} / \mathrm{V}$ in a screw cap test tube with constant stirring. The correct density of the turbidity standard was verified by using a spectrophotometer. The absorbance was 0.09 at $625 \mathrm{~nm}$. (Normal range is 0.08 to 0.10 at $625 \mathrm{~nm}$ ). Then the tube was capped and sealed tightly to prevent loss of evaporation.

\subsection{Inoculums Preparation}

Bacteria were subculture overnight on the nutrient agar medium and a loopful culture from the nutrient agar medium was inoculated into the nutrient broth. The broth was incubated at $37^{\circ} \mathrm{C}$. The turbidity of the growing broth culture was adjusted with sterile saline to obtain turbidity optically comparable to the $0.5 \mathrm{McF}$ arland Standard. This results in a suspension containing approximately $10^{8} \mathrm{cfu} / \mathrm{ml}$. 
Volume 1, Issue 2, Serial 3: September 2012

\subsection{Different concentration antibiotic solution preparation}

One gram of antibiotic was measured aseptically and was dissolved in $100 \mathrm{ml}$ phosphate buffer. It was mixed vigorously. In this way $10^{4} \mu \mathrm{g} / \mathrm{ml}$ antibiotic solution was obtained. $1 \mathrm{ml}$ from this solution was mixed with $99 \mathrm{ml}$ nutrient broth and made $10^{2} \mu \mathrm{g} / \mathrm{ml}$ solutions. Again from this solution $1 \mathrm{ml}$ was taken and mixed with $99 \mathrm{ml}$ nutrient broth and thus a final concentration $1 \mu \mathrm{g} / \mathrm{ml}$ solution was obtained.

By following serial dilution method different concentration of antibiotic solution were prepared. In this test $1 \mu \mathrm{g} / \mathrm{ml}, 2 \mu \mathrm{g} / \mathrm{ml}, 3 \mu \mathrm{g} / \mathrm{ml}, 4 \mu \mathrm{g} / \mathrm{ml}, 5 \mu \mathrm{g} / \mathrm{ml}, 6 \mu \mathrm{g} / \mathrm{ml}, 7 \mu \mathrm{g} / \mathrm{ml}$, $8 \mu \mathrm{g} / \mathrm{ml}, 9 \mu \mathrm{g} / \mathrm{ml}, 10 \mu \mathrm{g} / \mathrm{ml}$ concentration was used.

$0.1 \mathrm{ml}$ bacterial suspension which was compared with 0.5 MacFarland solution was transferred into $9.99 \mathrm{ml}$ saline water. After that, one drop of bacterial suspension containing saline water was inoculated into each different concentration antibiotic containing tubes.

This procedure was performed for both gram positive and gram negative bacteria. Then test tubes were incubated at $37^{\circ} \mathrm{C}$ for 48 hours. Finally turbidity was observed visually to determine MIC.

\subsection{Different concentration of antibiotic and metal complex preparation}

One gram of antibiotic and $1 \mathrm{gm}$ specific metal salt was measured aseptically and were dissolved in $100 \mathrm{ml}$ phosphate buffer. It was mixed vigorously. By following serial dilution method different concentration of antibiotic solution containing specific metal ion were prepared. In this test $1 \mu \mathrm{g}$ antibiotic and $1 \mu \mathrm{g}$ metal in $1 \mathrm{ml}, 2 \mu \mathrm{g}$ antibiotic and $2 \mu \mathrm{g}$ metal in $1 \mathrm{ml}$ and in such a way $10 \mu \mathrm{g}$ antibiotics and $10 \mu \mathrm{g}$ metal in $1 \mathrm{ml}$ solution was prepared and used in the test.

$0.1 \mathrm{ml}$ bacterial suspension which was compared with 0.5 MacFarland solutions was transferred into $9.99 \mathrm{ml}$ saline water. After that, one drop of bacterial suspension containing saline water was inoculated into each different concentration antibiotic with metal ion containing tubes. 
In our test we used $\mathrm{MgSO}_{4}, \mathrm{MnSO}_{4}, \mathrm{FeSO}_{4}, \mathrm{ZnSO}_{4}$ and $\mathrm{KCl}$ as the source of metal ion. This same procedure was maintained for each metal.

This procedure was performed for both gram positive and gram negative bacteria.

Then test tubes were incubated at $37^{\circ} \mathrm{C}$ for 48 hours. Finally turbidity was observed visually to determine MIC.

\subsection{Measurement of absorbance}

By using light absorbance technique, the growth of bacteria was measured at 590 $\mathrm{nm}$ in a spectrophotometer. Then the resistant pattern was analyzed by drawing a graph using the chart of absorbance in different concentration of antibiotic.

\section{Results}

\section{Spectral study}

In spectral studies, it was seen that Cephradine gives a sharp peak at $262 \mathrm{~nm}$, when the salts (Magnesium Sulfate, Manganese Sulfate, Ferrous Sulfate, Zinc Sulfate and Potassium Chloride) mixed with Cephradine in 1:1 ratio, the intensity of the peak of Cephradine changes remarkably i.e. absorption characteristics are altered due to interaction but the position of the compound do not shift. Spectral result presented in figure 1.

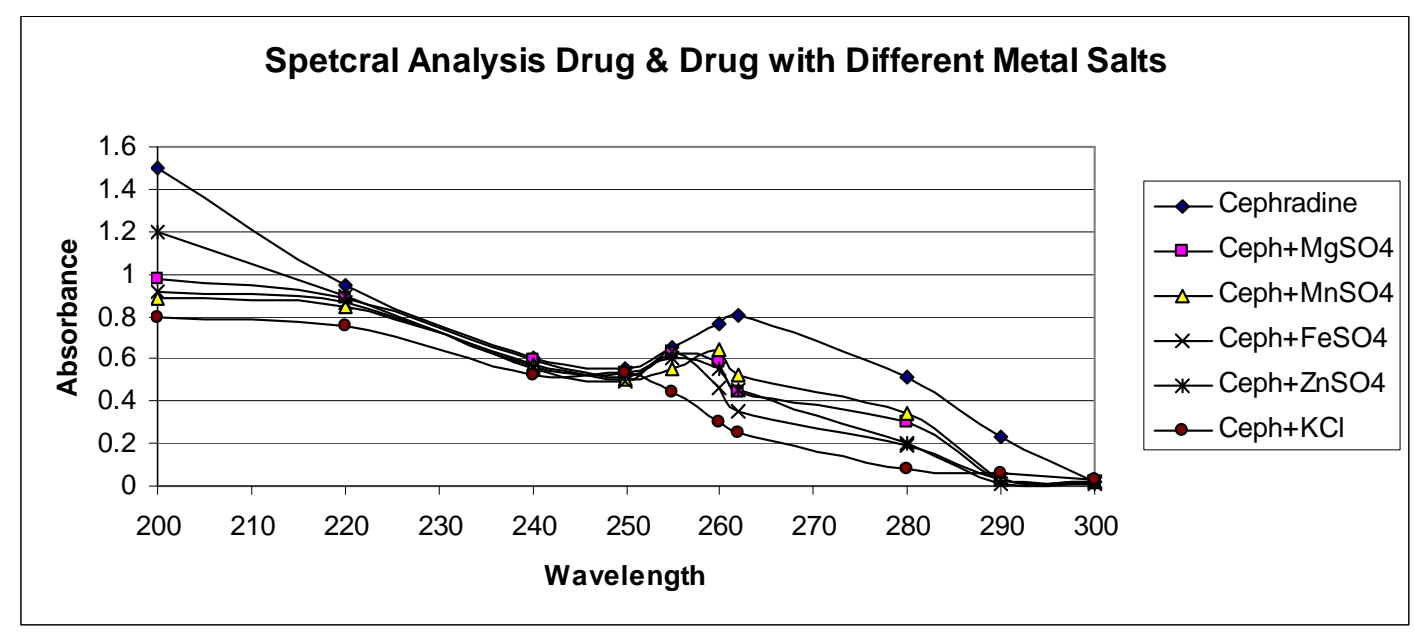

Figure 1: Combined Spectra of Drug \& Drug with different Essential Metal 


\section{Study of job's method}

The molar ratios of the complexes of Cephradine with metal salts (Magnesium Sulfate, Manganese Sulfate, Ferrous Sulfate, Zinc Sulfate and Potassium Chloride) were estimated by job's method of continuous variation. The observed absorbance values were measured in $\mathrm{pH} 7.4$ at various concentrations $\left(0.1 \times 10^{-5}\right.$ to $\left.0.9 \times 10^{-5} \mathrm{M}\right)$ of Cephradine with metal salts at $262 \mathrm{~nm}$. The Job's plots at 7.4 were obtained by plotting absorbance differences against the mole fraction of the drug Cephradine, which are presented in Figure 2.

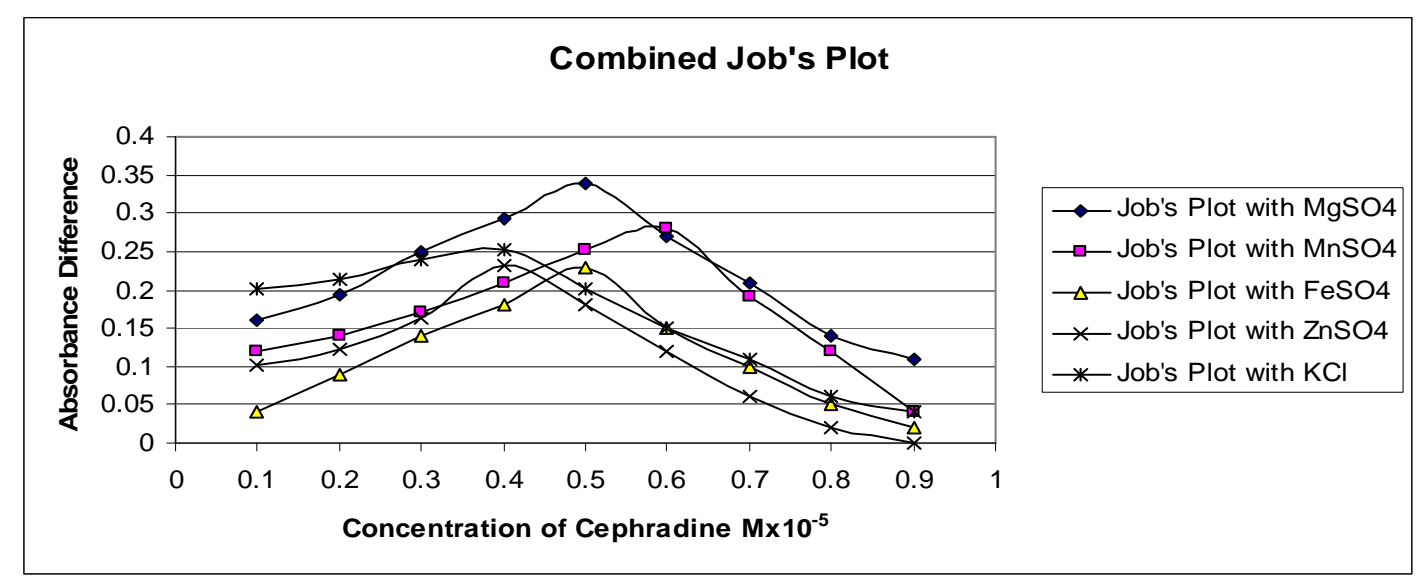

Figure 2: Job's plots for all metal salts after interaction with Cephradine.

\section{Study of Ardon's method}

Ardon's plot confirmed the formation of 1:1 complex of Cephradine with metal salts at $\mathrm{pH} 7.4$, since the method is valid for only 1:1 complexes. The Ardon's plots gave straight lines intercept which are presented in Fig.4 indicating the formation of 1:1 complexes drug Cephradine with Magnesium Sulfate, Manganese Sulfate, Ferrous Sulfate, Zinc Sulfate and Potassium Chloride. Results are presented in figure 3. 


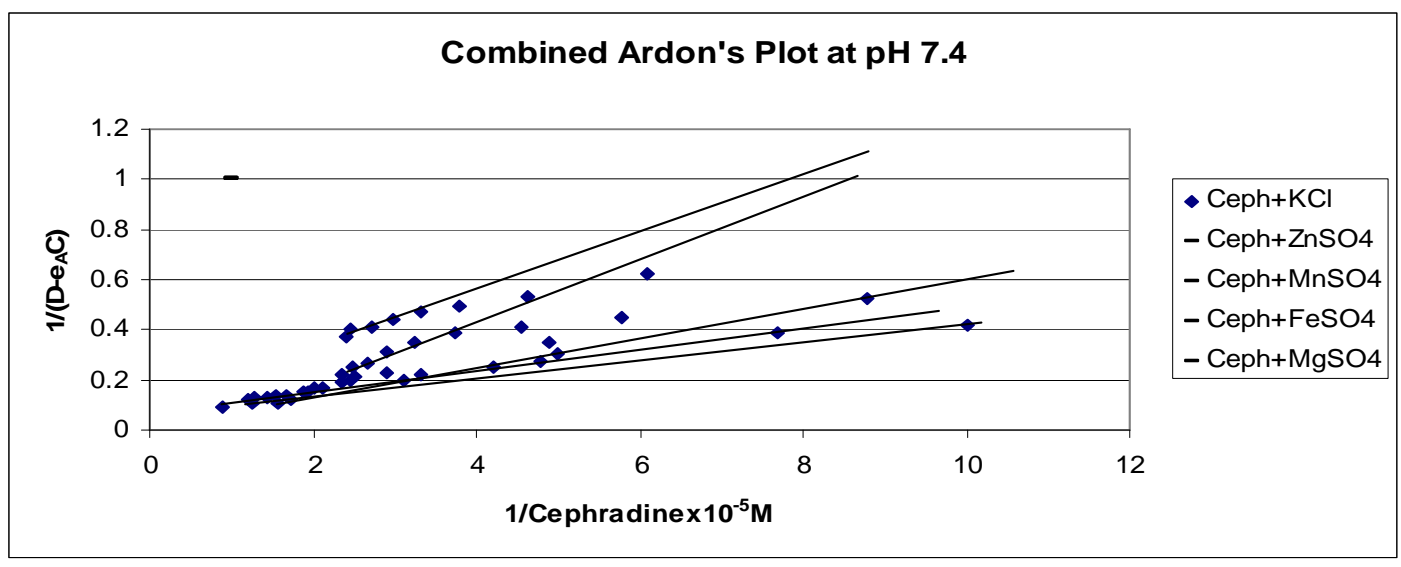

Figure 3: Represent Combined Ardon's plots at pH 7.4

\section{Estimation of Stability Constant}

The value of stability constant for the complexation of Cephradine with Magnesium Sulfate, Manganese Sulfate, Ferrous Sulfate, Zinc Sulfate and Potassium Chloride at $\mathrm{pH}$ 7.4, were obtained from the spectral data using Ardon's plot. The values for stability constant were calculated from the slopes and intercepts of the straight lines from these plots. It was seen from the Ardon's equation that the values of stability constant was given as (Intercept)/(slope). The value of intercept and slope were calculated by Least Squares Method using the following equation:

$y=m X+C$

The values of stability constants for the drug-metal system at $\mathrm{pH} 7.4$ are given in the Table 1.

Table1: Values of stability constant at $\mathrm{pH} 7.4$

\begin{tabular}{lc}
\hline Drug Metal complex & System stability Constant \\
Cephradine $+\mathrm{MgSO}_{4}$ & 1.437 \\
Cephradine $+\mathrm{MnSO}_{4}$ & 1.251 \\
Cephradine $+\mathrm{FeSO}_{4}$ & 1.335 \\
Cephradine $+\mathrm{ZnSO}_{4}$ & 0.983 \\
Cephradine $+\mathrm{KCl}$ & 0.795 \\
\hline
\end{tabular}




\section{Antibacterial study (MIC determination)}

The MIC of Cephradine after 1:1 interaction with the Magnesium Sulfate, Manganese Sulfate, Ferrous Sulfate, was found to be decreased for most of the organism as compared to the parent drug. The decreasing trends of MICs were observed for both of the gram positive and gram negative organisms. The intensity of absorbance also decreased remarkably for both gram positive and gram negative organisms.

The MIC of Cephradine after 1:1 interaction with the Zinc Sulfate and Potassium Chloride was found to be increased for most of the organism as compared to the parent drug. The increasing of MICs was observed for both of the gram positive and gram negative organisms. The intensity of increasing absorbance was also observed. Table: $2 A \& 2 B$ shows absorbance of the growth and Figure: $5 A$ \& 5B shows the comparison.

Table 2A: Absorbance of the growth of Gram Positive Bacteria containing dilution

\begin{tabular}{ccccccc}
\hline $\begin{array}{l}\text { Conc. of } \\
\begin{array}{c}\text { Cephradine } \\
\mu \mathrm{g} / \mathrm{ml}\end{array}\end{array}$ & Cephradine & $\begin{array}{l}\text { Cephradine } \\
+\mathrm{MgSO} 4\end{array}$ & $\begin{array}{c}\text { Cephradine } \\
+\mathrm{MnSO} 4\end{array}$ & $\begin{array}{c}\text { Cephradine } \\
+ \text { FeSO } 4\end{array}$ & $\begin{array}{c}\text { Cephradine } \\
+\mathrm{ZnSO} 4\end{array}$ & $\begin{array}{c}\text { Cephradine } \\
+\mathrm{KCl}\end{array}$ \\
1 & 0.652 & 0.301 & 0.31 & 0.195 & 0.716 & 0.85 \\
2 & 0.62 & 0.212 & 0.275 & 0.165 & 0.673 & 0.643 \\
3 & 0.59 & 0.146 & 0.241 & $\mathrm{NG}$ & 0.589 & 0.594 \\
4 & 0.527 & $\mathrm{NG}$ & 0.18 & $\mathrm{NG}$ & 0.536 & 0.523 \\
5 & 0.505 & $\mathrm{NG}$ & 0.155 & $\mathrm{NG}$ & 0.509 & 0.488 \\
6 & 0.425 & $\mathrm{NG}$ & $\mathrm{NG}$ & $\mathrm{NG}$ & 0.406 & 0.365 \\
7 & 0.35 & $\mathrm{NG}$ & $\mathrm{NG}$ & $\mathrm{NG}$ & 0.295 & 0.239 \\
8 & $\mathrm{NG}$ & $\mathrm{NG}$ & $\mathrm{NG}$ & $\mathrm{NG}$ & 0.214 & 0.176 \\
9 & $\mathrm{NG}$ & $\mathrm{NG}$ & $\mathrm{NG}$ & $\mathrm{NG}$ & $\mathrm{NG}$ & 0.132 \\
10 & $\mathrm{NG}$ & $\mathrm{NG}$ & $\mathrm{NG}$ & $\mathrm{NG}$ & $\mathrm{NG}$ & $\mathrm{NG}$ \\
\hline
\end{tabular}




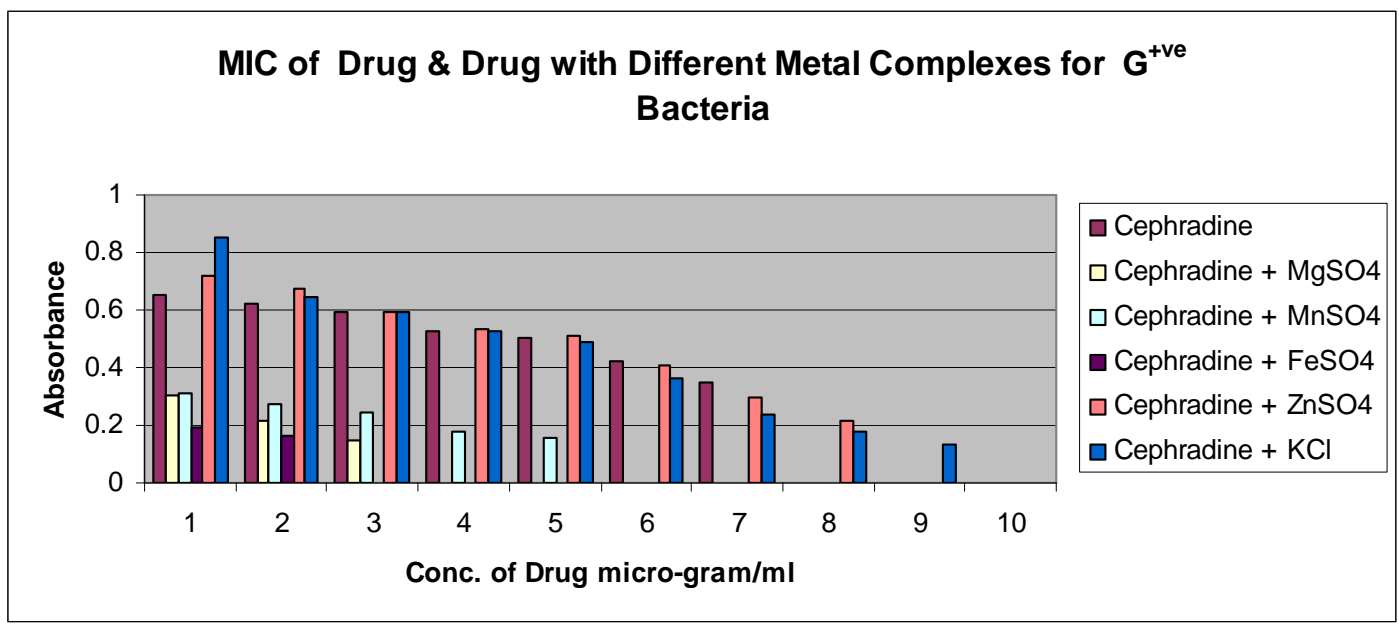

Figure: 5A shows comparison of variation of the growth of Gram Positive bacteria after using different metal with antibiotic

Table 2B: Absorbance of the growth of Gram Negative Bacteria containing dilution

\begin{tabular}{ccccccc}
\hline $\begin{array}{c}\text { Conc. of } \\
\text { Cephradine } \\
\mu \mathrm{g} / \mathrm{ml}\end{array}$ & Cephradine & $\begin{array}{l}\text { Cephradine } \\
+\mathrm{MgSO} 4\end{array}$ & $\begin{array}{l}\text { Cephradine } \\
+\mathrm{MnSO} 4\end{array}$ & $\begin{array}{l}\text { Cephradine } \\
+ \text { FeSO } 4\end{array}$ & $\begin{array}{l}\text { Cephradine } \\
+\mathrm{ZnSO} 4\end{array}$ & $\begin{array}{l}\text { Cephradine } \\
+\mathrm{KCl}\end{array}$ \\
1 & 0.714 & 0.325 & 0.401 & 0.21 & 0.975 & 0.85 \\
2 & 0.7 & 0.288 & 0.36 & 0.179 & 0.794 & 0.763 \\
3 & 0.659 & 0.169 & 0.281 & 0.145 & 0.625 & 0.701 \\
4 & 0.582 & $\mathrm{NG}$ & 0.25 & 0.137 & 0.516 & 0.58 \\
5 & 0.516 & $\mathrm{NG}$ & $\mathrm{NG}$ & 0.114 & 0.459 & 0.425 \\
6 & 0.455 & $\mathrm{NG}$ & $\mathrm{NG}$ & $\mathrm{NG}$ & 0.346 & 0.347 \\
7 & 0.38 & $\mathrm{NG}$ & $\mathrm{NG}$ & $\mathrm{NG}$ & 0.254 & 0.284 \\
8 & $\mathrm{NG}$ & $\mathrm{NG}$ & $\mathrm{NG}$ & $\mathrm{NG}$ & 0.156 & 0.176 \\
9 & $\mathrm{NG}$ & $\mathrm{NG}$ & $\mathrm{NG}$ & $\mathrm{NG}$ & $\mathrm{NG}$ & 0.12 \\
10 & $\mathrm{NG}$ & $\mathrm{NG}$ & $\mathrm{NG}$ & $\mathrm{NG}$ & $\mathrm{NG}$ & $\mathrm{NG}$ \\
\hline
\end{tabular}




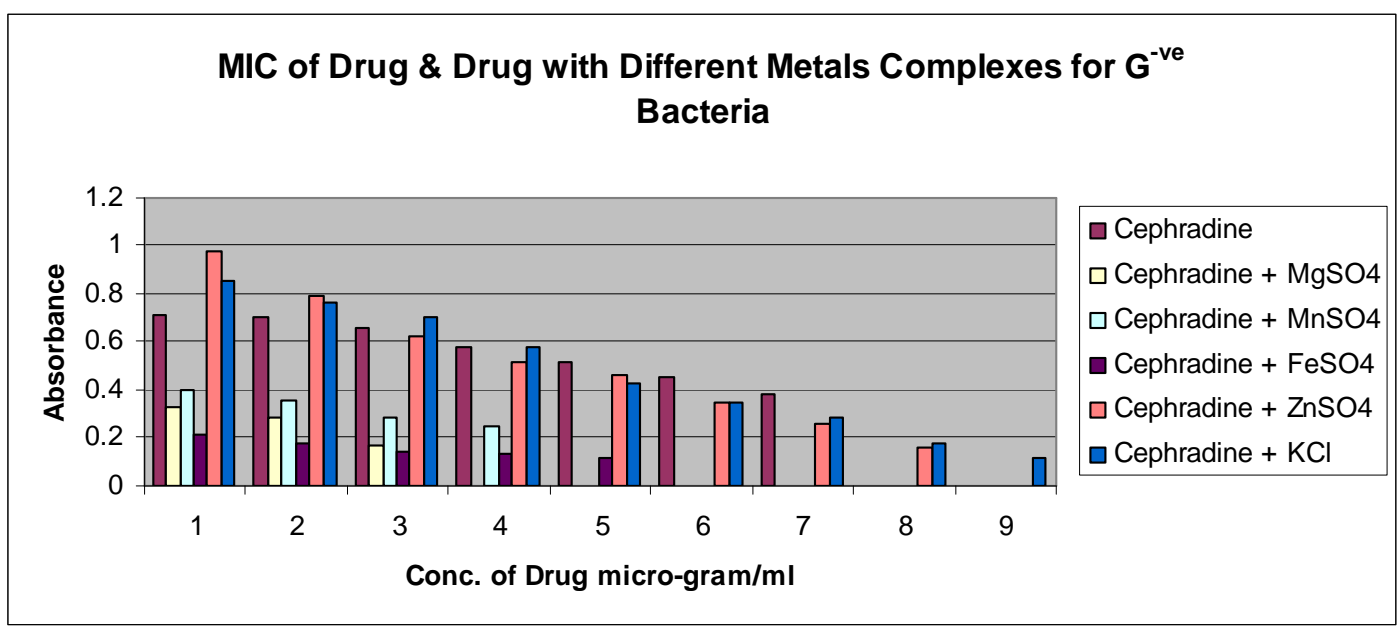

Figure 5B shows comparison of variation of the growth of Gram Negative bacteria after using different metal with antibiotic

\section{Discussion}

In the present work, the interaction of an important antibiotic, Cephradine with Magnesium Sulfate, Manganese Sulfate, Ferrous Sulfate, Zinc Sulfate and Potassium Chloride has been studied in the aqueous system at $\mathrm{pH} 7.4$ by a variety of physical method like inspection of spectral behavior, Job's method of continuous variation and Ardon's straight line plots by specrophotometry. From spectral study, it has been seen that Cephradine give a sharp peak at $262 \mathrm{~nm}$. When Magnesium Sulfate, Manganese Sulfate, Ferrous Sulfate, Zinc Sulfate and Potassium Chloride salt mixed with Cephradine at 1:1 ratio, the intensity of the peak of Cephradine changes remarkably, i.e absorption characteristics are altered due to interaction but the position of the compound do not shift. Job's plot has given the molar ratio of complexes of Cephradine and with metal salts. At pH 7.4 Cephradine forms strong $1: 1$ complexes with metal salts indicated as ' $N$ ' shaped curves. These curves may indicate strong kinetics of complexation between Cephradine \& metal salts. The Ardon's spectrophotometric plots also confirm the phenomenon of 1:1 complexation which is indicated by straight lines. The stability constant of the complex has estimated from this straight line plots using Ardon's equation.

The determined MIC of Cephradine was performed after 1:1 interaction with Magnesium Sulfate, Manganese Sulfate, Ferrous Sulfate, Zinc Sulfate and 
Potassium Chloride. Result was found to be decreased in minimum inhibitory concentration (MIC) for most of the organism as compared to the parent drug in presence of Magnesium Sulfate, Manganese Sulfate, Ferrous Sulfate. The decreasing trends in the MICs for both of the gram positive and gram negative organisms. That means the antimicrobial activity of Cephradine increased in presence of Magnesium Sulfate, Manganese Sulfate, Ferrous Sulfate. Result also was found to be increased in minimum inhibitory concentration (MIC) for most of the organism as compared to the parent drug in presence of Zinc Sulfate and Potassium Chloride. The increase in the MICs for both of the gram positive and gram negative organisms was observed. That means the antimicrobial activity of Cephradine decreased in presence of Zinc Sulfate and Potassium Chloride.

\section{Conclusion}

Finally it can be concluded that the antimicrobial activity is higher for $1: 1$ complexes of Cephradine with Magnesium Sulfate, Manganese Sulfate, Ferrous Sulfate than that of Cephradine alone. As a result, the intake of Cephradine with Magnesium Sulfate, Manganese Sulfate salt or Magnesium, Manganese and Ferrous complexes of Cephradine or the concurrent therapy can increase the antimicrobial activity of Cephradine. It is also observed that antimicrobial activity is lower for Cephradine complexes with Zinc sulfate and Potassium chloride. So we must be careful during concurrent therapy with Magnesium Sulfate, Manganese Sulfate, Ferrous Sulfate, Zinc Sulfate and Potassium Chloride.

\section{References}

1. Brithsh Pharmacopoeia (2002). CD Ver. 6, The Stationary Office London. P. Cefradine, pp.1-4.

2. Ryan, C.W., Simon, R.L. and Van Heyningen, E.M. (1969). Chemistry of cephalosporin antibiotics 13-desacetoxycephalosporins. The synthesis of cephalexin and some analogs. J.Med. Chem. 12(2): 310-313.

3. John H. Block, Edward B. Roche, Taito O. Soine, Charles O.Wilson; Inorganic Medicinal and Pharmaceutical Chemistry, India, 1986, 1, 213-234. 


\section{International Journal of Pharmaceutical and Life Sciences \\ ISSN 2305-0330 \\ Volume 1, Issue 2, Serial 3: September 2012}

4. Lambert, H.P. and O'Grady, F.W. (1992). Antibiotic and Chemotherapy, 6th ed. Churchill, Livingstone, Medical Division of Longman group U.K. Ltd., pp.72-135, 191-230.

5. Fong, I.W., Engelking, E.R. and Kirby, W.M.M. (1976). Relative inactivation by staphylococcus aureus of eight cephalosporin antibiotics. Antimicrob. Ag. Chemother. 9(6): 939-944.

6. Basker, M.J., Endmondson, R.A. and Sutherland, R. (1980). Comparative stabilities of penicillins and cephalosporins to staphylococcal beta lactamase and activities against staphylococcus aureus. J. Antimicrob. Chemother. 6(3): 333-341.

7. Hamilton-Miller, J.M.T. (1974). Comparative activity of ampicillin and seven cephalosporins against group D streptococci. J. Clin. Path. 27(10): 828-831.

8. Busch, D.F., Kureshi, L.A., Sutter, V.L. and Finegold, S.M. (1976). Susceptibility of respiratory tract anaerobes to orally administered penicillins and cephalosporins. Antimicrob. Agents Chemother. 10(4): 713-720.

9. McGowan, J.E. Jr., Garner, C., Wilcox, C. and Finland, M. (1974). Antibiotic susceptibility of gram-negative bacilli isolated from blood cultures. Results of test with 35 agents and strains from 169 patients at Boston city Hospital during 1972. Amer. J. Med. 57(2): 225-238.

10. Bill, N.J. and Washington, J.A.H. (1977). Comparison of in vitro activity of cephalexin, cephradine and cefaclor. Antimicrob. Agents Chemother. 11(3): 470-474.

11. Wise, R., Andrews, J.M., Dean, S. (1979). A pharmacological and in vitro comparison of three oral cehphalosporins. J. Antimicrob. Chemother. 5(5): 601-607.

12. Phillips, I., King, A., Warren, C. and Watts, B. (1976). The activity of penicillins and eight cephalosporins on Neisseria gonorrhoeae. J. Antimicrob. Chemother. 2: 31.

13. Selwyn, H. and Bakhtiar, M. (1977). Penicillin resistant gonococci. Brit. Med. J. 2(6079): 118-119.

14.Sinai, R., Hammerberg, S., Marks, M.I. and Pai, C.H. (1978). In vitro susceptibility of Haemophilus influenza to sulfamethoxazole trimethoprim and 
Volume 1, Issue 2, Serial 3: September 2012

cefaclor, cephalexin and cephradine. Antimicrob. Agents Chemother.13(5): 861-864.

15. Watanakunakorn, C. and Glotzbecker, C. (1979). Comparative susceptibility of Haemophilus species to cefaclor, cefamandole, and five other cephalosporins and ampicillin, chloramphenicol, and tetracycline. Antimicrob. Agents Chemother. 15(6): 836-838.

16. Goldstein, E.J.C., Kwork, Y.Y. and Sutter, V.L. (1983). Susceptibility of Gardnerella vaginalis to cephradine. Antimicrob. Agents Chemother. 24(3): 418-419.

17. Sirot, D., Glandlier, Y., Channal, M., Sirot, J. and Cizel, R. (1982). Statistical regression analysis for four new cephalosporins (authors transl). Pathol. Biol. 30(6): 357-362.

18. Messmer, J.C., Lecaillon, T.E., Bon, F. and Golg, H. (1983). In vitro comparison of the antibacterial activity of $1 \mathrm{st}$, $2 \mathrm{nd}$ and $3 \mathrm{rd}$ generation cephalosporins. Sem. Hosp. 59(34): 2389-2392.

19. Arthur Israel Vogel. Textbook of Quantitative Inorganic Analysis. 4th Edition. Longman (1978).

20. Ardon, M. , 1957. Oxidation of ethanol by ceric perchlorate. Oxidation of ethanol by ceric perchlorate, [Online]. 0, 1811. Available at: http://pubs.rsc.org/en/content/articlelanding/1957/jr/jr9570001811 [Accessed 02 August 2011]. 